\title{
Hydrologic impacts of sheep grazing on steep slopes in semiarid rangelands
}

\author{
BRADFORD P. WILCOX AND M. KARL WOOD
}

\section{Abstract}

Infiltration, sediment concentration of runoff, and sediment production from lightly grazed and ungrazed semiarid slopes were compared using a hand-portable rainfall simulator. The study slope was located in the Guadalupe Mountains of southeastern New Mexico. Average slope steepness was 50\%. The objective of this study was to determine the impacts of light grazing by sheep $(10 \mathrm{ha} / \mathrm{AU})$ on steep slope infiltrability and sediment production. Infiltrability on the grazed slopes was 12-17\% lower than on the ungrazed slopes. These results are comparable to what has been reported from moderate slope gradients. Sediment concentration of runoff from the lightly grazed slopes was significantly higher than from the ungrazed slopes only at the end of the dry run (45 min). Sediment production was significantly greater from the grazed slopes for the dry run, but not the wet run. Percentage difference of sediment production between the grazed and ungrazed slopes was well within the range published for moderate slope conditions. These data give no indication that steep slopes (30-70\%) in semiarid reglons are any more hydrologically sensitive to light grazing than are moderate slopes $(<10 \%)$.

Hydrologic processes on rangelands and the effects of land use on these processes are much better understood now than $\mathbf{3 0}$ years ago, in part because of rainfall simulation methodology. Rainfall simulation has been an especially valuable tool in evaluating the impacts of grazing management on rangeland hydrology. The use of rainfall simulation, however, has been largely limited to slope gradients less than $10 \%$. The hydrologic impact of grazing on steeper slopes has been littled studied.

By the removal of plant cover and trampling, grazing can result in increased soil compaction and crusting by raindrop impact. Soil organic matter and aggregation can also be reduced. All of which results in lower infiltration and higher sediment production. Busby and Gifford (1981) suggested that impacts of grazing are cumulative rather than instantaneous. They found that simply the removal of vegetation by clipping did not result in an immediate decrease in infiltration rate.

Grazing research to date indicates that heavy grazing, regardless of grazing system in place, causes reduced infiltration and increased sediment production (Warren et al. 1986). Hydrologic impacts of moderate and light grazing differ little from one another (Gifford and Hawkins 1978). In many cases sediment production and infiltration from moderate, light, and ungrazed pastures have differed little (Blackburn et al. 1982). Specialized grazing systems have not generally proved to be hydrologically advantageous over continuous grazing (Gifford and Hawkins 1978, Warren et al. 1986).

One might reasonably ask are steep slopes more hydrologically sensitive to grazing pressure? Do the generalities learned from previous grazing research apply to steep slopes? These are especially important questions in mountainous areas grazed by sheep, since sheep utilize steep slopes more than do cattle (McDaniel and Tiedeman 1981). The objective of this study was to assess the hydrologic impact (infiltration and sediment production) of sheep

Authors are hydrologist, USDA Agricultural Research Service, Northwest Watershed Research Center, 270 South Orchard, Boise 83705; and associate professor of range watershed management, Dept. of Animal and Range Sciences, New Mexico State University, Las Cruces 88003 .

New Mexico Agricultural Experiment Station Journal Article 1317.

Manuscript accepted 14 March 1988. grazing on steep slopes $(>30 \%)$ at light stocking rates in semiarid rangelands.

\section{Study Area}

The study was conducted in the northern Guadalupe Mountains of southeastern New Mexico. The Guadalupe Mountains are a dissected plateau of moderate to high relief (King 1948, Hayes 1964). The plateau runs northwestwardly, and is about $64 \mathrm{~km}$ long and 5 to $19 \mathrm{~km}$ wide. Width becomes greater towards the south. The western edge is defined by a great fault scarp known as the Guadalupe Rim. Field work was conducted on the Guadalupe Rim where slopes were generally $>30 \%$. Elevation of the study area ranges from about 1,200 to $2,000 \mathrm{~m}$. The climate is semiarid and is characterized by relatively mild winters and warm temperatures throughout the year. Average annual precipitation is about $50 \mathrm{~cm}$. Approximately $80 \%$ of the precipitation comes from May to October (Gehlbach 1967).

Soils in the study area developed from limestone or dolomite residuum and are shallow. Underlying bedrock begins at depths of 10 to $50 \mathrm{~cm}$. Textures are gravelly loams and gravelly clay loams. Soils are classified loamy-skeletal, carbonatic, mesic Lithic Calciustolls (Deama series) or clayey, mixed mesic Lithic Argiustolls (Encierro series) and are well drained with moderate permeability (USDA 1981). Rock outcrops are common.

Succulent desert and evergreen woodland formations are present in the study area (Gehlbach 1967). Common shrub and tree species are one-seed juniper (Juniperus monosperma (Engelm.) Sarg., three-leaf sumac (Rhus aromatica Ait. var flabelliformis Shinners), mountain mahogany (Cercocarpus montanus Raf.), skeleton-leaf goldeneye (Viguiera stenoloba Blake), and wavy leaf oak (Quercus undulata Torr.). Smooth-leaf sotol (Dasylirion leiophyllum Engelm.), lechuguilla agave (Agave lechugilla Torr.), and walkingstick cholla (Opuntia imbricata [Haworth] DC.) are common succulents. Major grasses are blue grama (Bouteloua gracilis), sideoats grama (Bouteloua curtipendula Michx.] Torrey), slim tridens (Tridens muticus [Torr.] Nash), curleyleaf muhly (Muhlenbergia setifolia Vasey), needle and thread (Stipa comata Trin. and Rupr.), and cliff muhly (Muhlenbergia polycaulis Schrilon).

The study area was made up of 2 Forest Service grazing allotments. One (1,500 ha) has been grazed for about 3 months during the winter for the last 10 years by $700-1,000$ sheep. Sheep did not uniformly graze the steep slopes available to them and some areas were essentially ungrazed. The other allotment has been grazed by cattle. Area ranchers and Forest Service personnel agree that cattle rarely venture out on the very steep slopes evaluated in this study. We therefore have assumed that the steep slopes in the allotment grazed by cattle are ungrazed by domestic livestock.

\section{Methods}

Hillel (1982) has pointed out the shortcomings of the term "infiltration capacity" and has proposed the term "infiltrability" in its place to "designate the infiltration flux resulting when water at atmospheric pressure is made freely available at the soil surface" (Hillel 1982 p. 212). We concur that "infiltrability" is a more appropriate term and have used it throughout this article.

In the summer of 1984, a hand-portable rainfall simulator (Wil- 
cox et al. 1986) was used to apply rainfall to flexible, oval shaped plots about $1 \mathrm{~m}^{2}$ in size. The rainfall simulator employed a single stationary nozzle that was placed $2.0 \mathrm{~m}$ above the plot. Rainfall application rate was $10.3 \mathrm{~cm} \mathrm{hr}^{-1}$. Drops varied from 0.8 to $2.0 \mathrm{~mm}$ in size. Median drop size was $1.2 \mathrm{~mm}$. Plots were constructed from sheet metal strips $10 \mathrm{~cm}$ wide and $355 \mathrm{~cm}$ long. Each end of the sheet metal strip was bolted to a runoff tray, forming an oval or circular shape. Flexible plots were lightly tamped into the soil and the lower inside borders were sealed with soil to prevent leakage. The soil seal was covered with a mulch layer to protect it from raindrop impact and subsequent soil particle detachment. Plot area was measured at each location using a grid constructed from 1.27-cm wire mesh.

Water was applied twice at each plot location. Application times were separated by about 16-24 h. Water was applied for $45 \mathrm{~min}$ during the first application (dry run) and 35 min during the second (wet run) to attain steady state infiltrability. Dry and wet runs were included in the analysis to increase the range in soil moisture conditions and to approximate field capacity conditions as well as dry or antecedent conditions. Immediately after the dry run, the plot was covered with clear polyethylene plastic to prevent evaporation.

Infiltrability was calculated as rainfall rate minus runoff rate. Other components of the water budget (surface water storage, interception storage, evaporation) were not accounted for in determining infiltration since they represented minor losses to the system and would have been difficult to determine for each plot. Total runoff $\left(1 \mathrm{~m}^{-2}\right)$ was collected and weighed for each 5-min interval that rainfall was applied.

Sediment concentration of the runoff was determined for 3 times during the dry and wet runs. These were at 5, 25, $45 \mathrm{~min}$ and 5, 20, $35 \mathrm{~min}$ for the dry and wet runs respectively. At sites 2,3 , and 4 the 5 -minute dry run sample was the first liter of runoff from the plot. At site 1 , sampling differed slightly in that the first minute of runoff was not included in the sample. Implications of this difference in sampling will be considered further in discussion of the results. Sediment production was calculated as:

$$
E=C_{1} R_{1}+C_{2} R_{2}+C_{3} R_{3}
$$

$E=$ total soil loss from plot (gm)

$\mathrm{C}_{1}=$ sediment concentration (SC) at $5 \mathrm{~min}\left(\mathrm{gml}^{-1}\right)$

$\mathrm{C}_{2}=(5 \mathrm{~min} \mathrm{SC}+25 \mathrm{~min} \mathrm{SC}) / 2\left(\mathrm{gml}^{-1}\right)$

$\mathrm{C}_{3}=(25 \mathrm{~min} \mathrm{SC}+45 \mathrm{~min} \mathrm{SC}) / 2\left(\mathrm{gml}^{-1)}\right.$

$R_{1}=$ total runoff (1) for first $5 \mathrm{~min}$

$R_{2}=$ total runoff (1) from 5-25 min

$R_{3}=$ total runoff (1) from $25-45 \mathrm{~min}$

Rainfall was simulated on 4 sites, each of which were about 0.1 ha (Table 1). Two sites were considered ungrazed. One of these sites (site 1,16 plots) was in the pasture ungrazed by sheep. The other one (site 2,8 plots) although in the pasture grazed by sheep was judged to be ungrazed. No evidence of grazing was noted. This site was quite steep and was located below a steep rock precipice making it poorly accessible. It was also far from water. The grazed sites were located below a heavily used bedding ground adjacent to a water source. These sites were the south (site 3,8 plots) and north (site 4,7 plots) tending slopes adjacent to an easily accessible saddle of moderate slope (20-30\%). There was ample evidence of sheep grazing on these sites. Since grazing was not uniformly distributed over the slopes, exact grazing intensity of sites 3 and 4 could not be determined. We judged these sites to be lightly grazed because of the vigor and composition of the vegetation and because slopes were steep (30-70\%). McDaniel and Tiedeman (1978) concluded that utilization by sheep in the Guadalupe Mountains dropped off markedly after slopes exceeded $35 \%$. Soils and vegetation were very similar across the 3 sites $(1,2,3)$ with a southerly aspect. Site 4 faced toward the north and had similar soils as the other sites but differed somewhat in species composition. Cliff muhley and wavyleaf oak were more abundant. Vegetation and soil characteristics,

Table 1. Summarized and averaged characteristics of each site. Where appropriate, standard errors are included in parentheses.

\begin{tabular}{|c|c|c|c|c|}
\hline \multirow[b]{2}{*}{ Characteristic } & \multicolumn{4}{|c|}{ Site } \\
\hline & 1 & 2 & 3 & 4 \\
\hline Grazed & no & no & yes & yes \\
\hline Plot \# & 16 & 8 & 8 & 7 \\
\hline Slope $(\%)$ & $51(2.6)$ & $54(1.7)$ & $49(2.0)$ & $50(2.4)$ \\
\hline Rock cover (\%) & $26.6(3.6)$ & $37.5(3.8)$ & $38.0(3.1)$ & $33.0(5.6)$ \\
\hline Grass cover $(\%)$ & $32.4(3.8)$ & $17.0(3.2)$ & $27.8(3.3)$ & $11.5(2.4)$ \\
\hline Forb cover (\%) & $1.7(0.5)$ & $0.4(0.1)$ & $0.3(0.2)$ & $4.3(0.9)$ \\
\hline Shrub cover $(\%)$ & $12.9(5.7)$ & $17.4,(4.4)$ & $6.8(5.2)$ & $11.0(5.1)$ \\
\hline Litter cover $(\%)$ & $5.4(1.1)$ & $6.9(1.6)$ & $7.5(1.5)$ & $11.9(2.9)$ \\
\hline Grass biomass (gm-m ${ }^{-2}$ ) & $93.4(8.6)$ & $80.4(12.3)$ & $100.0(11.3)$ & $69.3(11.6)$ \\
\hline Forb biomass $\left(\mathrm{gm}-\mathrm{m}^{-2}\right)$ & $8.6(2.1)$ & $1.4(0.5)$ & $2.6(1.2)$ & $15.5(2.1)$ \\
\hline Shrub biomass $\left(\mathrm{gm}-\mathrm{m}^{-2}\right)$ & $468.8(222.9)$ & $158.8(49.3)$ & $166.5(145.1)$ & $202.1(98.3)$ \\
\hline Litter biomass & $75.9(39.1)$ & $68.6(11.7)$ & $49.4(12.0)$ & $105.3(117.4)$ \\
\hline Soil depth (cm) & $25.0(1.2)$ & $31.2(2.5)$ & $24.9(2.8)$ & $30.4(3.2)$ \\
\hline Bulk density* $\left(\mathrm{gm}-\mathrm{cm}^{-3}\right)$ & $0.97(0.02)$ & $0.99(0.04)$ & $1.03(0.04)$ & $0.88(0.03)$ \\
\hline Organic carbon ${ }^{*}(\%)$ & $5.3(0.3)$ & $4.7(0.6)$ & $5.8(0.6)$ & $6.5(0.4)$ \\
\hline sand* $(\%)$ & $37.8(0.6)$ & $37.9(0.4)$ & $38.9(0.6)$ & $40.9(0.3)$ \\
\hline clay* $(\%)$ & $19.8(0.6)$ & $15.6(0.3)$ & $18.3(0.6)$ & $16.3(0.6)$ \\
\hline Dry run $\mathrm{CI}^{* *}(\mathrm{~cm})$ & $6.5(0.3)$ & $6.5(0.5)$ & $5.9(0.3)$ & $5.6(0.6)$ \\
\hline Wet run $\mathrm{Cl}^{* *}(\mathrm{~cm})$ & $4.4(0.2)$ & $4.1(0.4)$ & $3.3(0.2)$ & $3.9(0.6)$ \\
\hline Dry run $S P(k g-h a)^{* * *}$ & $455(151)$ & $1739(854)$ & $1091(476)$ & $1730(821)$ \\
\hline Wet run SP (kg-ha)*** & $595(288)$ & $970(348)$ & $908(391)$ & $996(357)$ \\
\hline Dry sed. conc. $5 \mathrm{~min}\left(\mathrm{gm}-\mathrm{I}^{-1}\right)$ & $3.1(0.9)$ & $14.3(5.8)$ & $10.5(3.3)$ & $10.0(3.4)$ \\
\hline Dry sed. conc. $25 \mathrm{~min}\left(\mathrm{gm}^{-1} \mathrm{1}^{-1}\right)$ & $2.3(0.5)$ & $6.3(2.3)$ & $3.0(0.8)$ & $3.3(0.9)$ \\
\hline Dry sed. conc. $45 \mathrm{~min}\left(\mathrm{gm}-1^{-1}\right)$ & $1.8(0.3)$ & $3.1(1.1)$ & $2.3(0.5)$ & $3.7(0.9)$ \\
\hline Wet sed. conc. $\left.5 \mathrm{~min}\left(\mathrm{gm}^{-1}\right)^{-1}\right)$ & $4.9(2.4)$ & $4.9(1.2)$ & $5.1(2.0)$ & $6.2(1.8)$ \\
\hline Wet sed. conc. $\left.20 \mathrm{~min}\left(\mathrm{gm}^{-1}\right)^{-1}\right)$ & $1.9(0.3)$ & $3.3(1.0)$ & $2.0(0.5)$ & $3.0(0.8)$ \\
\hline Wet sed. conc. $35 \mathrm{~min}\left(\mathrm{gm}^{-1}{ }^{-1}\right)$ & $1.2(0.2)$ & $2.7(0.5)$ & $1.6(0.4)$ & $3.1(0.7)$ \\
\hline
\end{tabular}

* sampled at 0-5 cm depth

**CI-cumulative infiltration

***SP - sediment production 
as well as infiltration and sediment production, are summarized by site on Table 1. A detailed description of the methods used to measure vegetation and soils within each plot are given by Wilcox et al. (1988).

Data were analyzed using a nested one-way analysis of variance (Steel and Torrie 1980). Sites were nested within grazing treatment and used as the error term. Significant differences among sites were determined using individual plots (sampling error) as the error term.

\section{Results and Discussion}

Infiltrability of the grazed sites was lower than ungrazed ones (Fig. 1). The magnitude of the difference in infiltration between the

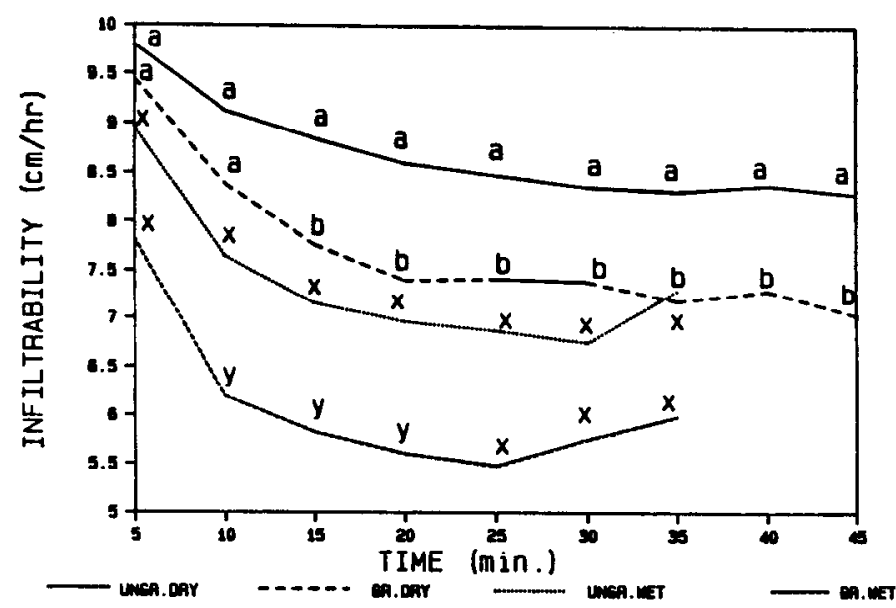

Fig. 1. Dry and wet run infiltrability for grazed and ungrazed slopes. Statistical comparisons were made within dry or wet runs. Differences in letter denote significant difference $(\mathrm{P} \leq 0.05)$.

grazed and ungrazed sites was about the same for the dry and wet runs. Significant differences occurred more often during the dry run. During the wet run, site differences accounted for much of the variabilty; the analysis of variance indicated significant differences among sites but not grazing treatments. Total infiltration of the grazed sites was $11 \%$ and $17 \%$ less than the ungrazed sites for the dry and wet runs respectfully (Table 2). Differences, however, were only significant for the dry run.

Table 2. Cumulative infiltration $(\mathrm{CI})$ and sediment production for the grazed and ungrazed sites.

\begin{tabular}{lccc}
\hline & \multicolumn{2}{c}{ CI (cm) } & \\
\cline { 2 - 3 } & ungrazed & grazed & $\%$ change \\
\hline Dry run & 6.52 & $5.78 *$ & $-11 \%$ \\
Wet run & 4.31 & 3.56 & $-17 \%$ \\
& \multicolumn{3}{c}{ Sediment Production (kg/ha) } \\
Dry run & 883 & $1390 *$ & $+57 \%$ \\
Wet run & 719 & 949 & $+32 \%$ \\
\hline
\end{tabular}

"Indicates a significant difference $(P \leq 0.05)$

Based on their review of the literature, Gifford and Hawkins (1978) concluded that, on the average, light/moderate grazing results in about $25 \%$ lower infiltration than on ungrazed areas. In many studies no significant difference in infiltration between ungrazed and light or moderate grazing was noted. Data reported here suggest that infiltration of steep slope soils is no more sensitive to light grazing than is infiltration of more moderate soils.

The increased infiltrability towards the end of the wet run is interesting. One possibility is that the release of entrapped air caused higher infiltrability. This has been shown experimentally by
Jarret and Fritton (1978). Entrapped air compresses during the infiltration process "and the increased air pressure reduces the hydraulic head gradient driving the infiltration process, reducing infiltration rate" (Jarret and Fritton 1978, p. 901). Eventually internal pressure will increase such that air escapes and infiltrability increases.

Average sediment concentration was generally greater from the grazed sites than the ungrazed ones (Fig. 2). Absolute differences in

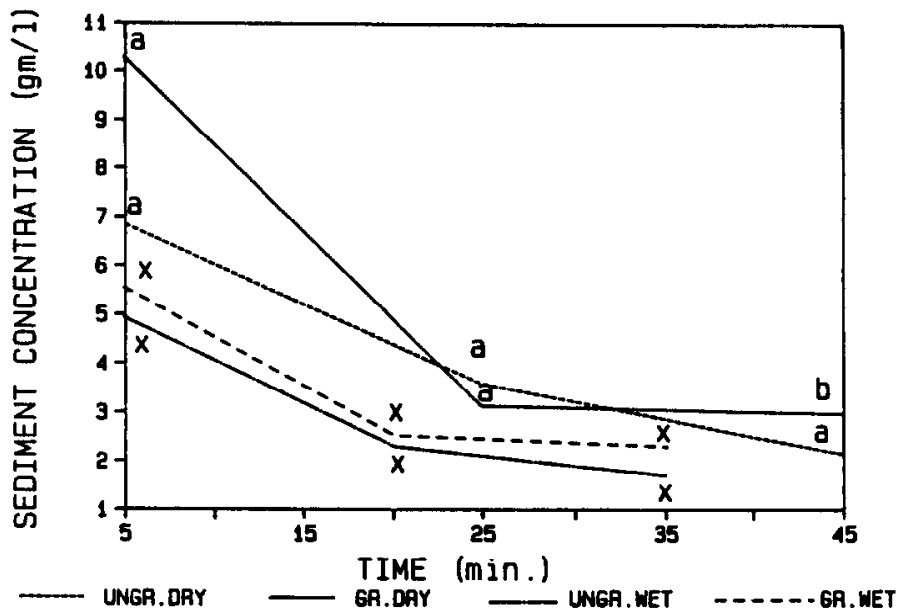

Fig. 2. Dry and wet run sediment concentration for the grazed and ungrazed slopes. Statistical comparisons were made within the dry or wet runs. Difference in lettering denote significant differences $(\mathrm{P} \leq 0.05)$.

sediment concentration were highest at the beginning of the dry run. This however is probably an artifact of sampling error. Note that dry run sediment concentration at 5 minutes is much lower from site 1 than from any of the other sites (Table 1). After 5 minutes sediment concentration from site 1 is similar to sediment concentration of site 3. Apparently by not sampling the first minute of dry run runoff at site 1 we missed a substantial slug of sediment.

Grazed sediment concentration was only significantly higher than ungrazed sediment concentration at the very end of the dry run; although absolute differences in sediment concentration were not great. Sediment concentration was the least variable at the end of runoff. During the wet runs the sediment concentration from the grazed and ungrazed sites was very similar.

The high sediment concentration at the beginning of runoff was due to the initially high availability of easily erodible fines (Emmett 1978). High initial sediment concentration of overland flow has been observed by others as well (Lowdermilk and Sundling 1950, Swanson et al. 1965). Schreiber and Renard (1978) reported similar trends in sediment concentrations of ephemeral flow from semiarid washes in Arizona. Also note sediment concentration at the beginning of the wet run was greater than the sediment concentration at the end of the dry run. This indicates that additional loose fines were made available in the interlude between rainfall simulation events, most likely caused by the wetting and drying process (Emmett 1978) or the weakening of soil aggregates by wetting.

Sediment production was greater from the grazed sites than the ungrazed ones, but only significantly so during the dry run (Table 2). Recall, however, that the 5-minute dry run sediment concentration recorded for site 1 was lower than it would have been if the first minute of runoff had been sampled; as it was for the other sites. For this reason the real difference in dry run sediment production between the grazed and ungrazed sites is attributed wholly to greater runoff (lower infiltrability) from the grazed sites, rather than higher sediment concentration. Site differences accounted for most of the wet run variability in sediment production; the analysis of variance indicated significant differences among sites but not 
grazing treatments.

Regardless of grazing treatment, sediment production was quite high from these steep slopes. Moderate slopes $(<10 \%)$ in the same study area produced only one ninth of the sediment that was produced from these slopes (Wilcox and Wood 1986).

Studies conducted at Fort Stanton, New Mexico comparing ungrazed to moderately grazed (by cattle) ranges have shown sediment production to be several times greater from moderately grazed ranges. Gamougoun et al. (1984) found sediment production to be highly variable. Even though sediment production was on the average 4 times higher from the grazed pasture $(155 \mathrm{~kg} / \mathrm{ha})$ than the ungrazed one $(34 \mathrm{~kg} / \mathrm{ha})$ differences were not significant. Weltz and Wood (1986) reported significantly greater sediment production from moderately grazed pastures $(300 \mathrm{~kg} / \mathrm{ha})$ than ungrazed ones $(100 \mathrm{~kg} / \mathrm{ha})$. In contrast others have found little difference in sediment production between moderately/light grazed pastures and ungrazed ones (Currie 1975). In light of results from previous grazing - watershed research, the response of sediment production on these steep slopes to light grazing was well within the norm. In fact the percentage increase reported here was much lower than that reported by many other studies on more moderate slopes.

\section{Conclusions}

(1) Infiltrability of steep slopes was slightly lowered by light sheep grazing. Other studies on more moderate slopes have reported similar results.

(2) Sediment production is highly variable and its response to grazing varies both temporally and spatially. Little absolute difference in sediment production of the treatments was observed. That which was, was attributed to higher runoff from the grazed slopes, as little true difference in sediment concentration of the runoff was detected. The relative difference in sediment production between the grazed and ungrazed slopes was lower than what has generally been reported from moderate semiarid slopes.

(3) Data reported here give no indication that steep slopes in semiarid areas are any more hydrologically sensitive to light grazing than are moderate slopes.

\section{Literature Citted}

Blackbum, W.H., R.W. Knight, and M.K. Wood. 1982. Influence of grazing on the watershed: A state of the art. Texas Agr. Exp. Sta. Rep. MP1496.

Busby, F.E., and G.F. Gifford. 1981. Effects of livestock grazing on infiltration and erosion rates measured on chained and unchained pinon-juniper sites in southeastern Utah. J. Range Manage. 34:400-405.
Currie, P.o. 1975. Grazing management of ponderosa pine-bunchgrass ranges of the central Rocky Mountains: the status of our knowledge. Forest Serv. Res. Pap. RM-159.

Emmett, W.W. 1978. Overland flow. p. 145-177. In: M.J. Kirkby (ed.). Hillslope Hydrology. John Wiley, New York.

Gamougoum, N.D., R.P. Smith, M. K. Wood, and R.D. Pieper. 1984. Soil, vegetation and hydrologic responses to grazing management at Fort Stanton, New Mexico. J. Range Manage. 37:538-541.

Gehlbach, F.R. 1967. Vegetation of the Guadalupe Escarpment, New Mexico-Texas. Ecology 48:404-419.

Gifford, G.F., and R.H. Hawkins. 1978. Hydrologic impact of grazing on infiltration: a critical review. Water Resour. Res. 14:305-313.

Hayes, P.T. 1964. Geology of the Guadalupe Mountains, New Mexico. U.S. Geol. Survey Prof. Pap. 446.

Hillel, D. 1982. Introduction to soil physics. Academic Press, New York.

Jarrett, A.R., and D.D. Fritton. 1978. Effect of entrapped soil air on infiltration. Trans. ASAE. 21:901-906.

King, P.B. 1948. Geology of the southern Guadalupe Mountains, Texas. U.S. Geol. Survey Prof. Pap. 215.

Lowdermilk, W.C., and H.L. Sundling. 1950. Erosion pavement formation and significance. Trans. Amer. Geophys. Union. 31:96-100.

McDaniel, K.C., and J.A. Tiedeman. 1981. Sheep use on mountain winter range in New Mexico. J. Range Manage. 34:102-104.

Schreiber, H.A., and K.G. Renard. 1978. Runoff water quality from varying land used in southeastern Arizona. J. Range Manage. 31:274-279.

Steel, R.D.G., and J.H. Torrie. 1980. Principles and procedures of statistics. McGraw-Hill, New York.

Swanson, N.P., A.R. Dedrick, and H.E. Weakly. 1965. Soil particles and aggregates transported in runoff from simulated rainfall. Trans. ASAE. 8:437-440.

USDA. 1981. Soil survey of Otero area, New Mexico, parts of Otero, Eddy and Chavez Counties. USDA Soil Exp. Sta.

Warren, S.D., W.H. Blackburn, and C.A. Taylor. 1986. Effects of season and stage of rotation cycle on hydrologic conditions of rangeland under rotation grazing. J. Range Manage. 39:486-490.

Weltz, M., and M.K. Wood. 1986. Short duration grazing in central New Mexico: Effects on sediment production. J. Soil Water Cons. 41:262-266.

Wilcox, B.P., and M.K. Wood. 1986. Factors influencing infiltration and erosion in the Guadalupe Mountains of New Mexico. In: H.J. MorelSeytoux and J.W. Warner (eds.). Proceedings AGU Front Range Branch Hydrology Days. 6:111-122.

Wilcox, B.P., M.K. Wood, and J.M. Tromble. 1988. Factors influencing infiltrability on semiarid mountain slopes. J. Range Manage. 41:197-206.

Wilcox, B.D., M.K. Wood, J.M. Tromble, and T.J. Ward. 1986. A handportable single nozzle rainfall simulator designed for use on steep slopes. J. Range Manage. 39:375-377. 